\title{
Effect of Propionic to Acetic Acid Ratio on Denitrifying Phosphorus Removal and Nitrous Oxide Production
}

\author{
Ya-jing Li ${ }^{1,2, a}$, Li-ping Sun ${ }^{1,2, b}$, Shu-ping Zheng ${ }^{1,2, c}$ \\ ${ }^{1}$ Environmental and Municipal Engineering Department, TCU,Tianjin,300384,China \\ ${ }^{2}$ Tianjin Key Laboratory of Water Quality Science and Technology, Tianjin, 300384, China \\ ayajingli79@163.com, bslpyqs@vip.sina.com, czsp865@126.com
}

Keywords: Denitrifying phosphorus removal, Propionic to acetic acid ratio, $\mathrm{PHA}, \mathrm{N}_{2} \mathrm{O}$ Abstract. In this paper, four lab-scale sequencing batch reactors (SBRs) operated with anaerobic/anoxic configuration were long-term cultured, respectively with different ratios of propionic to acetic acid as carbon sources. Effects of propionic to acetic acid ratio on polyhydroxyalkanoates (PHA) formation, denitrifying phosphorus removal and nitrous oxide $\left(\mathrm{N}_{2} \mathrm{O}\right)$ production were investigated. Results showed that with the propionic to acetic acid ratio increased, the anaerobic synthesis of PHA reduced, and (PHV+PH2MV)/PHA ratio increased, furthermore, the rate of PHA degradation in the anoxic phase decreased, ultimately leading to more $\mathrm{N}_{2} \mathrm{O}$ production. System running efficiency with the phosphorus removal rate of $93.33 \%$, nitrogen removal rate of $77.48 \%$ and anoxic $\mathrm{N}_{2} \mathrm{O}-\mathrm{N}$ production to denitrified nitrogen rate of $4.15 \%$ was best when acetic acid was the sole carbon source.

\section{Introduction}

Denitrifying phosphorus removal, which can achieve simultaneous denitrification and phosphorus removal, is a novel biological nutrient removal technology. Denitrifying phosphorus removal occurs due to the capacity of denitrifying phosphorus accumulating organisms (DPAOs) to use nitrate and/or nitrite as an electron acceptor for phosphorus removal instead of oxygen. When compared with conventional enhanced biological phosphorus removal (EBPR) processes, the denitrifying phosphorus removal process can reduce the need for aeration by $30 \%$, as well as reduce sludge production and the demand for carbon sources by $50 \%{ }^{[1]}$. These characteristics benefit significantly for the municipal wastewater treatment, especially for the low influent $\mathrm{C} / \mathrm{N}$ municipal wastewater treatment where the lack of carbon sources effects the nutrient removal efficiency. However, it was reported that a significant amount of $\mathrm{N}_{2} \mathrm{O}$ was produced in this process ${ }^{[2]}$. which is of significant environmental con-cern due to the high global warming potential of $\mathrm{N}_{2} \mathrm{O}$. This finding significantly diminishes the overall benefits of the denitrifying phosphorus removal and limits the prospect of implementing this process in wastewater treatment plants.

$\mathrm{N}_{2} \mathrm{O}$ is a by-product of microbial denitrification in denitrifying phosphorus removal, complete deni-trification from nitrate $\left(\mathrm{NO}_{3}{ }^{-}\right)$to molecular nitrogen $\left(\mathrm{N}_{2}\right)$ consists of four reduction steps, with nitrite $\left(\mathrm{NO}_{2}{ }^{-}\right)$, nitric oxide (NO) and $\mathrm{N}_{2} \mathrm{O}$ as reaction intermediates. However, under certain conditions, $\mathrm{N}_{2} \mathrm{O}$ has been found to be the final product instead of an intermediate ${ }^{[3-6]}$. The mechanism for $\mathrm{N}_{2} \mathrm{O}$ production in the denitrifying phosphorus removal process may not have been described properly to date, the possible reasons are as follows: (1) PHA have been reported to be a possible inducer of $\mathrm{N}_{2} \mathrm{O}$ emissions when utilized as growth substrate and the availability of external growth substrate is limited ${ }^{[7-10]}$. Itokawa et al. sug-gested that at relatively low $\mathrm{COD} / \mathrm{N}$ ratios, a higher $\mathrm{N}_{2} \mathrm{O}$ concentration could be observed due to incom-plete denitrification caused by the lack of external carbon sources $^{[11]}$. However, Adouani et al. found a lack of correlation between the types of carbon source with the amount of $\mathrm{N}_{2} \mathrm{O}$ produced ${ }^{[12]}$. It has also been observed that COD-limited conditions did not necessarily increase $\mathrm{N}_{2} \mathrm{O}$ accumulation ${ }^{[13]}$. (2) In denitrifying phosphorus removal systems, the composition of PHA(including poly- $\beta$-hydroxybutyrate (PHB), poly- $\beta$-hydroxyvalerate(PHV) and poly- $\beta$-hydroxy -2 -methylvalerate (PH2MV)) produced by DPAOs dur-ing the anaerobic period varies based on the carbon sources. However, DPAOs are unable to metabolize these different types 
of PHA at the same rate in the subsequent anoxic phase ${ }^{[14-15]}$. Therefore, the use of different carbon sources may lead to different properties of phosphorus metabolism and $\mathrm{N}_{2} \mathrm{O}$ emission. At present, few have considered the impact of intracellular PHA on $\mathrm{N}_{2} \mathrm{O}$ accumulation in denitrifying phosphorus removal process, a large number of research are need to be done.

Little is known about the long-term effects of carbon sources on $\mathrm{N}_{2} \mathrm{O}$ production in DPAOs dominant systems. In this study, the effects of different ratio of propionic to acetic acid on $\mathrm{N}_{2} \mathrm{O}$ production were investigated using four lab-scale anaerobic/anoxic (A/An) reactors to reveal the characteristics of $\mathrm{N}_{2} \mathrm{O}$ production during denitrification phosphorus removal using different carbon sources, as well as the relationship between carbon sources and the amount and composition of PHA synthesized. Aiming at providing a process control strategy to minimize $\mathrm{N}_{2} \mathrm{O}$ production while maintaining effective nitrogen and phosphorus removal.

\section{Materials and methods}

Reactor set-up and operation. Four sealed laboratory-scale SBRs with a working volume of 4.5 L were seeded with activated sludge from the WWTP in Tianjin, which routinely achieved EBPR. The SBRs in this study were maintained at $20 \pm 1^{\circ} \mathrm{Cand}$ operated under anaerobic-anoxic condi-tions. It was operated with four $6 \mathrm{hr}$ cycles per day. Each cycle consisted of an anaerobic period (90 min), and anoxic period $(210 \mathrm{~min})$, with the remainder of the cycle time $(60 \mathrm{~min})$ for settling, decanting, and idle. During the filling phase $3.15 \mathrm{~L}$ of simulated domestic wastewater was introduced into the reactor using peristaltic pumps on timers. At the beginning of anoxic phase, $0.2 \mathrm{~L}$ nitrate solution $(1.24 \mathrm{~g} \mathrm{~N}$ $\mathrm{L}^{-1}$ ) was pumped into the reactor with a constant flow rate. SBRs was mixed using stirrer in the anaerobic and anoxic stage. Wastewater was poured into jars for the SBRs per day. Sludge retention time (SRT) was controlled at approximately 15 days by drawing the sludge from the reactor at the end of the anoxic period. The MLSS was kept at $3000 \mathrm{mg} / \mathrm{L}$. It took about three months before a stable nitrogen and phosphorus removal was achieved in four SBRs. Thereafter, the experiments reported below were conducted.

Synthetic wastewater. The four SBRs were supplied with different propionic to acetic ratios synthetic wastewater(as shown in Tab.1) containing VFA $\left(220 \mathrm{mg} / \mathrm{L}\right.$ as COD basis), $\mathrm{NH}_{4} \mathrm{Cl}(15 \mathrm{mg} / \mathrm{L}$ as $\mathrm{NH}_{4}{ }^{+}-\mathrm{N}$ basis $), \mathrm{KH}_{2} \mathrm{PO}_{4}\left(10 \mathrm{mg} / \mathrm{L}\right.$ as $\mathrm{PO}_{4}{ }^{3-}-\mathrm{P}$ basis $), \mathrm{KNO}_{3}\left(55 \mathrm{mg} / \mathrm{L}\right.$ as $\mathrm{NO}_{3}{ }^{-}-\mathrm{N}$ in the anoxic phase $)$ and trace element solution. The trace element solution consisted of the following compounds per liter: $0.1 \mathrm{mg} \mathrm{ZnCl}_{2}, 0.5 \mathrm{mg} \mathrm{MgSO}_{4}, 0.5 \mathrm{mg} \mathrm{FeCl} 3 \cdot 6 \mathrm{H}_{2} \mathrm{O}, 0.1 \mathrm{mg} \mathrm{MnSO}_{4} \cdot \mathrm{H}_{2} \mathrm{O}, 0.1 \mathrm{mg} \mathrm{KI}, 0.5 \mathrm{mg}$ $\mathrm{CaCl}_{2}, 0.1 \mathrm{mg} \mathrm{H}_{2} \mathrm{BO}_{4}, 0.1 \mathrm{mg} \mathrm{NiCl}$.

Tab.1 Composition of main carbon sources and their concentrations in four SBRs

\begin{tabular}{llll} 
Reactor & $\begin{array}{l}\text { Acetic } \\
\left(\mathrm{mmol}-\mathrm{C} \cdot \mathrm{L}^{-1}\right)\end{array}$ & $\begin{array}{l}\text { Propionic } \\
\left(\mathrm{mmol}-\mathrm{C} \cdot \mathrm{L}^{-1}\right)\end{array}$ & $\begin{array}{l}\text { Propionic/Acetic } \\
\left(\text { mol-C mol-C }{ }^{-1}\right)\end{array}$ \\
\hline R-A & 6.875 & 0 & - \\
R-B & 4.342 & 2.171 & $1 / 2$ \\
R-C & 2.063 & 4.125 & $2 / 1$ \\
R-D & 0 & 5.893 & - \\
\hline
\end{tabular}

Analytical methods. The liquid samples were immediately filtered through Millipore filter units $\left(0.45 \mu \mathrm{m}\right.$ pore size) for the analysis of $\mathrm{NH}_{4}{ }^{+}-\mathrm{N} 、 \mathrm{NO}_{3}{ }^{-}-\mathrm{N} 、 \mathrm{NO}_{2}{ }^{-}-\mathrm{N} 、 \mathrm{PO}_{4}{ }^{3-}-\mathrm{P} 、$ MLSS and MLVSS which were measured in accordance with Standard Methods for the Examination of Water and Wastewater ${ }^{[16]}$. Total nitrogen (TN) was calculated as the sum of $\mathrm{NH}_{4}{ }^{+}-\mathrm{N}, \mathrm{NO}_{3}{ }^{-}-\mathrm{N}$ and $\mathrm{NO}_{2}{ }^{-}-\mathrm{N}$.

The $\mathrm{N}_{2} \mathrm{O}$ concentrations in the gas samples were analyzed using a gas chromatograph (GC) (Perkin Elmer Clarus 500, USA) equipped with an electron capture detector (ECD). The GC was equipped with a main column (Porapak Q 80/100 mesh, $6 \mathrm{~m} \times 1 / 8$ inch). A $1 \mathrm{~mL}$ sample loop and a 6 port valve were used to inject the gas samples. The temperatures of the columns and the ECD were $60^{\circ} \mathrm{C}$ and $300^{\circ} \mathrm{C}$, respectively. A mixture of $95 \% \mathrm{Ar}+5 \% \mathrm{CH} 4$ was used as the carrier gas. The dissolved $\mathrm{N}_{2} \mathrm{O}$ was measured by $\mathrm{GC}$ using a headspace method. The equilibrium temperature and 
time were $70^{\circ} \mathrm{C}$ and $1 \mathrm{~h}$, respectively. $\mathrm{N}_{2} \mathrm{O}$ was quantified using the standard curves generated from certified standard gases (National Institute of Metrology, PR China).

Acetic acid and Propionic acid were measured using an Perkin Elmer Clarus 500 gas GC equipped with a $300 \times 0.32 \mathrm{~mm} \times 0.5 \mu \mathrm{m}($ length $\times \mathrm{ID} \times$ film $)$ Elite-FFAP column and a flame ionization detector (FID) at $220^{\circ} \mathrm{C}$. PHB, PHV and PH2MV were measured using an PERSEE GC1100 gas GC equipped with a $30 \times 0.32 \mathrm{~mm} \times 0.25 \mu \mathrm{m}($ length $\times \mathrm{ID} \times$ film $)$ SE-54 col-umn and a flame ionization detector (FID) at $250^{\circ} \mathrm{C}$ according to the method described by Oehmen et al ${ }^{[17]}$. The total PHA in the samples was calculated as the sum of the measured PHB, PHV and PH2MV.

\section{Results and discussion}

Effects of different carbon sources on denitrifying phosphorus removal and $\mathrm{N}_{\mathbf{2}} \mathrm{O}$ production. Comparison of $\mathrm{N}$ and P removal performance in four SBRs. As showed in Fig. 1, of the four SBRs, the higher the propionic/acetic acid ratio the less the phosphorus release were observed. This coincides well with other studies that have suggested that an increase in the propionic/acetic ratio led to less phosphorus release ${ }^{[18]}$.

After the four reactors were fed with $\mathrm{KNO}_{3}$ solution, denitrification and phosphorus uptake occurred simultaneously. The highest phosphorus removal was obtained in R-A, while the lowest was observed in R-D, which were $88.99 \%, 85.45 \%, 80.95 \%$ and $74.51 \%$ respectively. Moreover, the added $\mathrm{NO}_{3}{ }^{-}-\mathrm{N}$ was rapidly reduced and this reduction was accompanied by the accumulation and reduction of $\mathrm{NO}_{2}{ }^{-}-\mathrm{N}$, which resulted in corresponding $\mathrm{TN}$ removal efficiencies of $79.71 \%, 78.57 \%$ $77.71 \%$ and $76.00 \%$, respectively. These findings indicated that, as the amount of propionate acid added increased, the denitrifying phosphorus removal decreased.
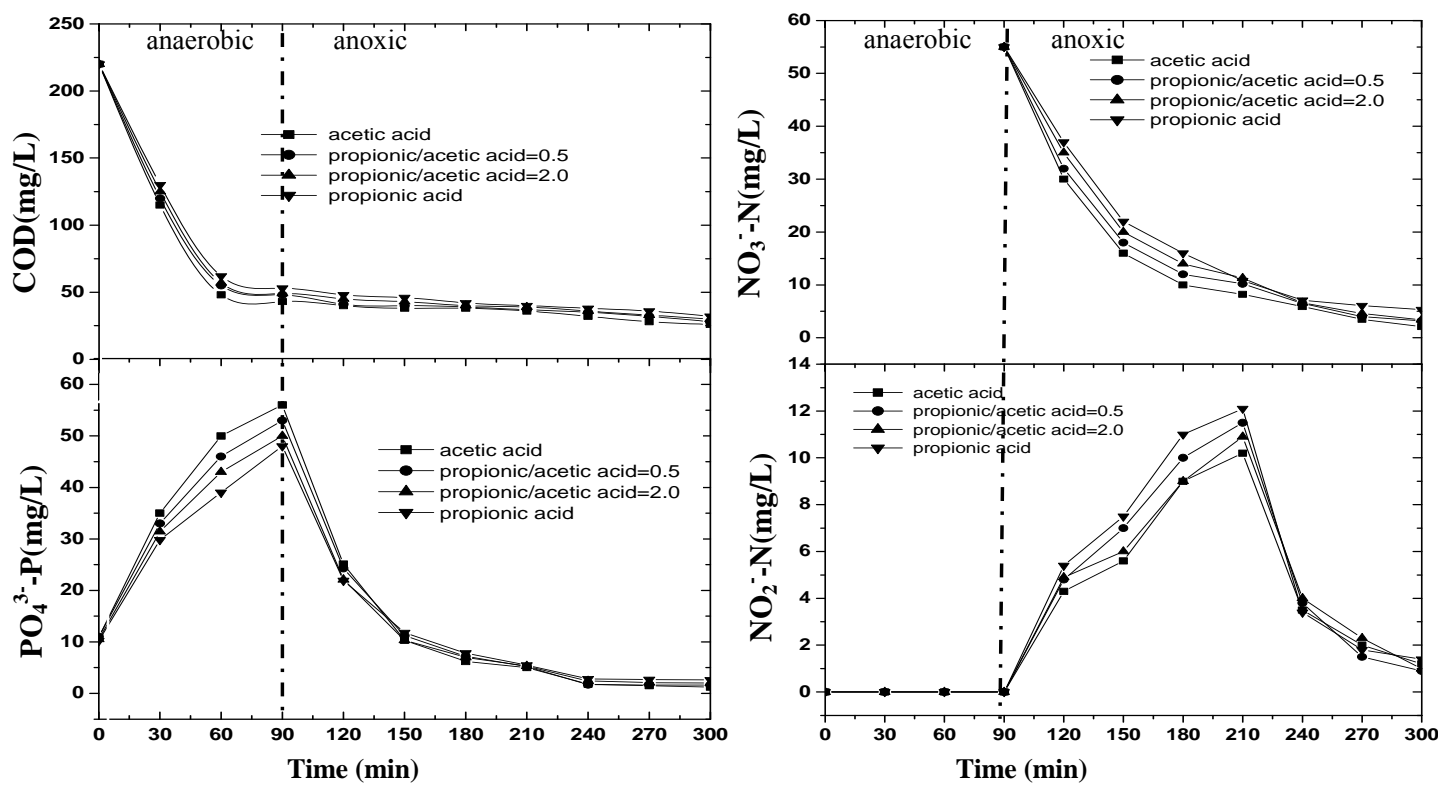

Fig.1 Variations in COD, nitrogen, phosphorus during one cycle in four SBRs

Effects of carbon sources on the transformation of PHA and $\mathbf{N}_{\mathbf{2}} \mathbf{O}$ production. Fig. 2 showed the transformations of PHA in the four SBRs. During the anaerobic phase, as the percentage of added propionate increased, the PHA synthesis decreased from 97.0, 84.4, 76.0 to $58.0 \mathrm{mg} / \mathrm{g}$-MLSS. Moreover, a decrease and an increase occurred in the fractions of formed PHB and PHV+PH2MV respectively (as shown in Tab.2). During the anoxic phase, the amounts of PHA degradation in the four SBRs were 106.8, 98.2, 86.0 and $68.0 \mathrm{mg} / \mathrm{g}$-MLVSS respectively, suggesting that increasing propionic acid content results in decreased PHA synthesis and oxidation. 
Tab.2 Comparison of $\mathrm{N}$ and $\mathrm{P}$ removal and $\mathrm{N}_{2} \mathrm{O}$ production in the four SBRs

\begin{tabular}{lllll}
\hline Item & R-A & R-B & R-C & R-D \\
\hline Anaerobic PHA synthesis (mg/g-MLVSS) & 97.00 & 84.40 & 76.00 & 58.00 \\
Anaerobic PHB synthesis (mg/g-MLVSS) & 77.31 & 60.29 & 35.76 & 12.45 \\
AnaerobicPHV+PH2MVsynthesis (mg/g-MLVSS) & 19.69 & 24.11 & 40.24 & 45.55 \\
(PHV+PH2MV)/PHA (\%) & 20.30 & 28.57 & 52.95 & 78.53 \\
P removal efficiency (\%) & 88.99 & 85.45 & 80.95 & 74.51 \\
Denitrification efficiency (\%) & 79.71 & 78.57 & 77.71 & 76.00 \\
Anoxic $\mathrm{N}_{2} \mathrm{O}$ production (mg N/L) & 2.23 & 2.50 & 2.60 & 2.90 \\
Ratio of anoxic $\mathrm{N}_{2} \mathrm{O}-\mathrm{N}$ production to denitrified nitrogen (\%) & 4.15 & 5.00 & 5.78 & 6.30 \\
\hline
\end{tabular}

Fig.2 also showed the variations in total $\mathrm{N}_{2} \mathrm{O}$ concentrations in the four SBRs. During the anaerobic phase, no $\mathrm{N}_{2} \mathrm{O}$ production was detected in any of the reactors. However, after the $\mathrm{KNO}_{3}$ solution was pulse added at the end of the anaerobic period, a remarkable increase in the $\mathrm{N}_{2} \mathrm{O}$ concentration occurred in all reactors. Consequently, the ratios of $\mathrm{N}_{2} \mathrm{O}-\mathrm{N}$ production to the TN removal were $4.15 \%, 5.00 \%, 5.78 \%$ and $6.30 \%$ respectively. Obviously, the ratio of $\mathrm{N}_{2} \mathrm{O}-\mathrm{N}$ production to $\mathrm{TN}$ removal increased with the increasing of propionate/acetate acid ratio.
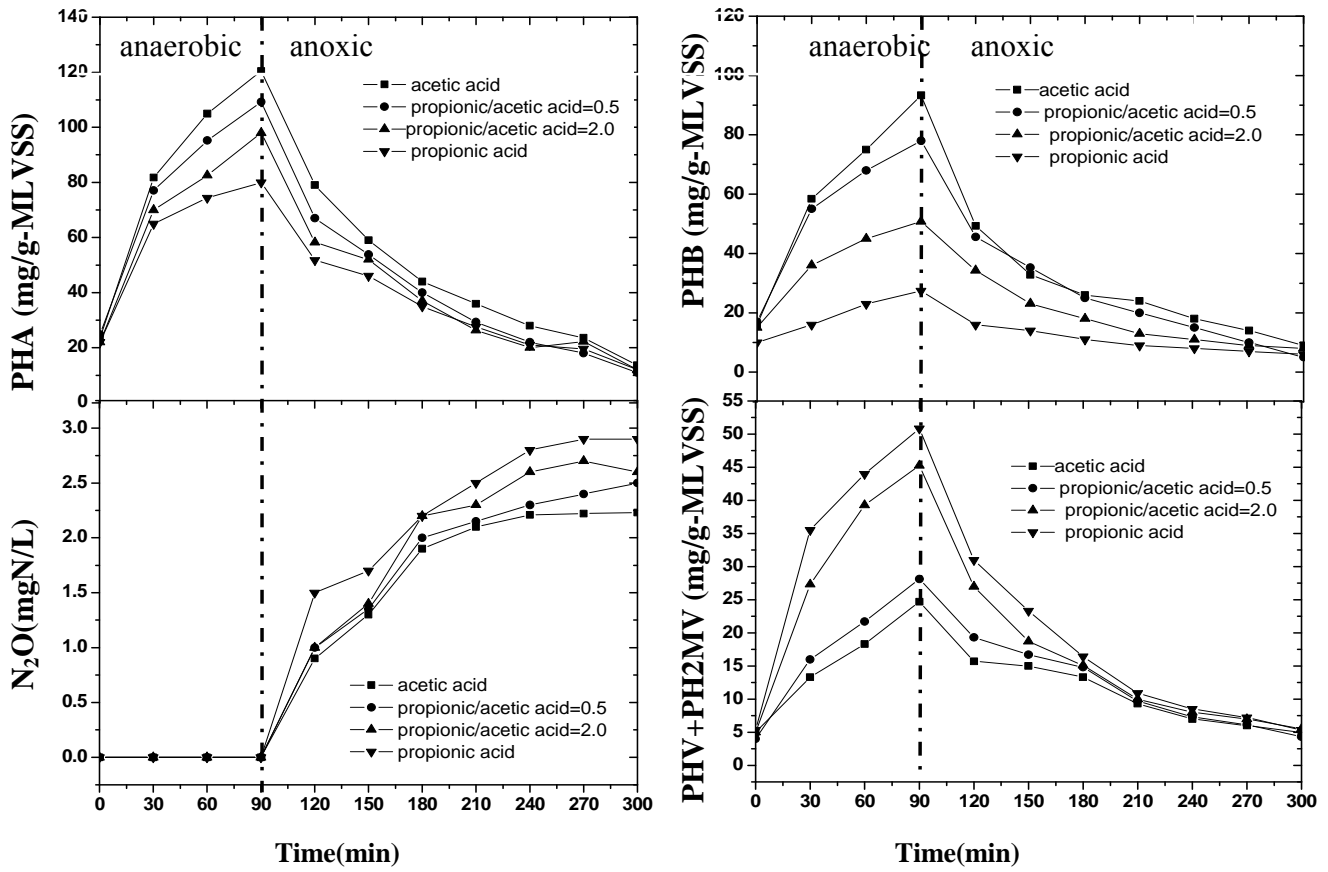

Fig.2 Variations of PHA and $\mathrm{N}_{2} \mathrm{O}$ in four SBRs with different carbon sources

From the above mentioned study we can see that the amount of anaerobically synthesized PHA had a significant effect on denitrification phosphorus removal efficiency as well as $\mathrm{N}_{2} \mathrm{O}$ production. The reduction of $\mathrm{N}_{2} \mathrm{O}$ is the last step of denitrification, which makes it more difficult for $\mathrm{N}_{2} \mathrm{O}$ reductase (Nos) to compete for electrons than other enzymes, particularly when the amount of the anaerobically synthesized PHA is low. Therefore, if more PHA is synthesized, more carbon sources are available for denitrification and the PHA degradation rate can be improved. This ultimately leads to a lower ratio of $\mathrm{N}_{2} \mathrm{O}-\mathrm{N}$ production to denitrified nitrogen.

Internal carbon source type may also be an important factor influencing $\mathrm{N}_{2} \mathrm{O}$ production. With the increasing of $(\mathrm{PHV}+\mathrm{PH} 2 \mathrm{MV}) / \mathrm{PHA}$ ratio in the four SBRs, the corresponding $\mathrm{N}_{2} \mathrm{O}$ generation rate increases. These findings suggest that more $\mathrm{PHV}+\mathrm{PH} 2 \mathrm{MV}$ leads to higher $\mathrm{N}_{2} \mathrm{O}$ production. As the carbon source, $\mathrm{PHB}$ and $\mathrm{PHV}+\mathrm{PH} 2 \mathrm{MV}$ denitrification rate is different, this may have different effects on the activity of denitrification enzymes, eventually also affected the $\mathrm{N}_{2} \mathrm{O}$ generation. 
$\mathrm{PHV}+\mathrm{PH} 2 \mathrm{MV}$ denitrification rate was slower than that of PHB, PHA containing higher proportion of PHB may be more suitable as a denitrification internal carbon source, thereby producing a low content of $\mathrm{N}_{2} \mathrm{O}$.

\section{Conclusion}

In the anaerobic-anoxic sequencing batch reactors, the effects of different ratios of propionic to acetic acid on the efficiency of phosphorus and nitrogen removal and the transformations of PHA and $\mathrm{N}_{2} \mathrm{O}$ were investigated. In the anaerobic stage, the increase of propionic fraction caused less PHB, more PHV and PH2MV, and less total PHA synthesis. This directly stimulated $\mathrm{N}_{2} \mathrm{O}$ production. The $\mathrm{N}_{2} \mathrm{O}-\mathrm{N}$ production to TN removal ratios were $1.20,1.39$ or 1.52 times higher, respectively, when biomass acclimatized with acetate/propionate or propionate than when acetate alone was used. In addition, the TP removal efficiency decreased from $88.99 \%$ to $85.45 \%, 80.95 \%$ or $74.51 \%$, respectively, and the TN removal efficiency declined from $79.71 \%$ to $78.57 \%, 77.71 \%$ or $76.00 \%$, respectively, after the carbon sources was switched from acetate to acetate/propionate or propionate.

\section{Acknowledgements}

This work was financially supported by the outstanding young teacher support program (03140602).

\section{References}

[1] T. Kuba, M.C.M. Van Loosdrecht, J.J. Heijnen, Water Res. ,30(1996), 1702-1710.

[2] Y. Zhou, M. Pijuan, Z.G. Yuan, Water Res., 42(2008), 3207-3217.

[3] S. Otte, N.G. Grobben, L.A. Robertson, et al. Appl. Environ. Microb., 62(1996), 2421-2426.

[4] R.v. Schulthess, M. Kühni, W. Gujer, Water Res., 29(1995), 215-226.

[5] K. Hanaki, Z. Hong, T. Matsuo, Water Sci. Technol., 26(1992), 1027-1036.

[6] R. Lemaire, R. Meyer, A. Taske, et al., J. Biotechnol., 122(2006), 62-72.

[7] S. Schalk-Otte, R.J. Seviour, J.G. Kuenen, et al., Water Res. ,34(2000), 2080-2088.

[8] W.Y. Wang, S.Y. Ma, B. Li, et al., Bioresource Technol. ,170(2014), 175-182.

[9] Cong Li, Ting Wang, Nan Zheng, et al., Bioresour. Technol., 141 (2013),160-166.

[10] Y.Y. Wang, J.F. Zhang, Z.X. Xing, et al., Bioresour. Technol., 101(2010) ,98-104.

[11] H. Itokawa, K. Hanaki, T. Matsuo, Water Res., 35(2001), 657-664.

[12] N. Adouani, T. Lendormi, L. Limousy, et al., Resour. Conserv. Recy. ,54(2010), 299-302.

[13] J.R. Zhang, S.Y. Wang, I.C.E.E.T. 2(2009), 511-514.

[14] A. Oehmen, Z.G. Yuan, L.L. Blackall, et al., Biotechnol. Bioeng., 91(2005) ,162-168.

[15] Y. Zhou, L. Melvin, H. Soekendro, et al., J. Environ. Sci. , 24(2012), 1616-1623.

[16] S.E.P.A. Chinese, Water and Wastewater Monitoring methods, fourth ed., Chinese Environmental Science Publishing House, Beijing, China, 2002.

[17] A. Oehmen, B. Keller-Lehmann, R.J. Zeng, et al., J. Chromatogr. A, 1070(2005),131-136.

[18] H.J. Li, Y.G. Chen, G.W. Gu, Bioresour. Technol. ,99(2008), 4400-4407. 